Cambridge University Press

978-1-107-06288-7 - Ecosystem Services: From Concept to Practice

Edited by Jetske A. Bouma and Pieter J. H. Van Beukering

Copyright Information

More information

\title{
Ecosystem Services
}

\section{From Concept to Practice}

\author{
EDITED BY \\ JETSKE A. BOUMA \\ Institute for Environmental Studies, VU University Amsterdam \\ Dutch Environmental Assessment Agency \\ and \\ PIETER J. H. VAN BEUKERING \\ Institute for Environmental Studies, VU University Amsterdam
}


Cambridge University Press

978-1-107-06288-7 - Ecosystem Services: From Concept to Practice

Edited by Jetske A. Bouma and Pieter J. H. Van Beukering

Copyright Information

More information

\section{CAMBRIDGE UNIVERSITY PRESS}

University Printing House, Cambridge CB2 8BS, United Kingdom

Cambridge University Press is part of the University of Cambridge.

It furthers the University's mission by disseminating knowledge in the pursuit of education, learning and research at the highest international levels of excellence.

www.cambridge.org

Information on this title: www.cambridge.org/9781107062887

(C) Cambridge University Press 2015

This publication is in copyright. Subject to statutory exception and to the provisions of relevant collective licensing agreements, no reproduction of any part may take place without the written permission of Cambridge University Press.

First published 2015

Printed in the United Kingdom by TJ International Ltd. Padstow, Cornwall A catalog record for this publication is available from the British Library

Library of Congress Cataloging in Publication data

Ecosystem services : from concept to practice / edited by Jetske A. Bouma, Pieter J. H. van Beukering.

pages $\mathrm{cm}$

ISBN 978-1-107-06288-7 (hardback)

1. Ecosystem services. I. Bouma, Jetske A. II. Beukering, Pieter van. QH541.15.E267.E276 2015

$577^{\prime} .1-\mathrm{dc} 23$

2014032242

ISBN 978-1-107-06288-7 Hardback

Cambridge University Press has no responsibility for the persistence or accuracy of URLs for external or third-party internet websites referred to in this publication, and does not guarantee that any content on such websites is, or will remain, accurate or appropriate. 